
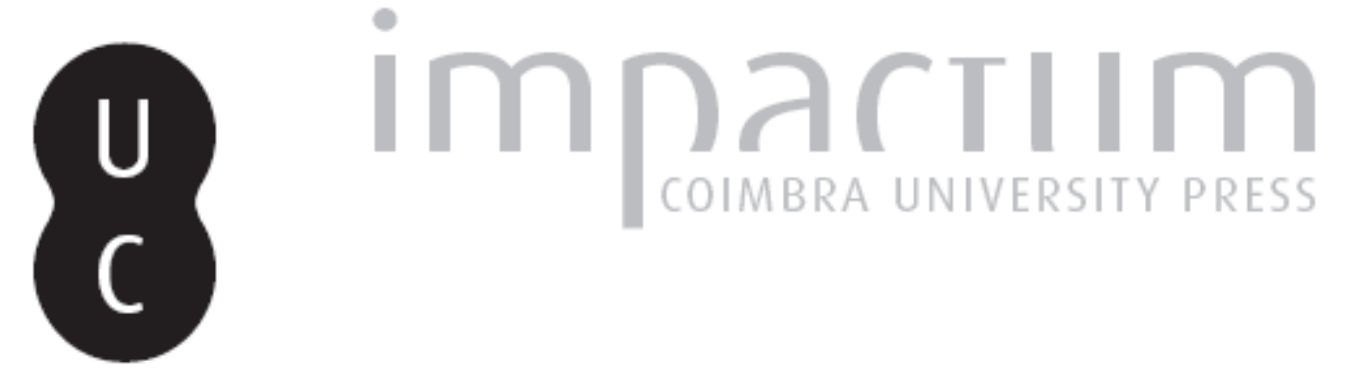

\title{
Crise e enciclopedismo: a tarefa dos intelectuais segundo Bento Caraça
}

Autor(es): $\quad$ Pita, António Pedro

Publicado por: Imprensa da Universidade de Coimbra

URL persistente:

URl:http://hdl.handle.net/10316.2/43725

DOI:

DOI:https://doi.org/10.14195/2183-8925_24_12

Accessed : $\quad$ 26-Apr-2023 14:49:43

A navegação consulta e descarregamento dos títulos inseridos nas Bibliotecas Digitais UC Digitalis, UC Pombalina e UC Impactum, pressupõem a aceitação plena e sem reservas dos Termos e Condições de Uso destas Bibliotecas Digitais, disponíveis em https://digitalis.uc.pt/pt-pt/termos.

Conforme exposto nos referidos Termos e Condições de Uso, o descarregamento de títulos de acesso restrito requer uma licença válida de autorização devendo o utilizador aceder ao(s) documento(s) a partir de um endereço de IP da instituição detentora da supramencionada licença.

Ao utilizador é apenas permitido o descarregamento para uso pessoal, pelo que o emprego do(s) título(s) descarregado(s) para outro fim, designadamente comercial, carece de autorização do respetivo autor ou editor da obra.

Na medida em que todas as obras da UC Digitalis se encontram protegidas pelo Código do Direito de Autor e Direitos Conexos e demais legislação aplicável, toda a cópia, parcial ou total, deste documento, nos casos em que é legalmente admitida, deverá conter ou fazer-se acompanhar por este aviso.

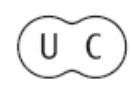



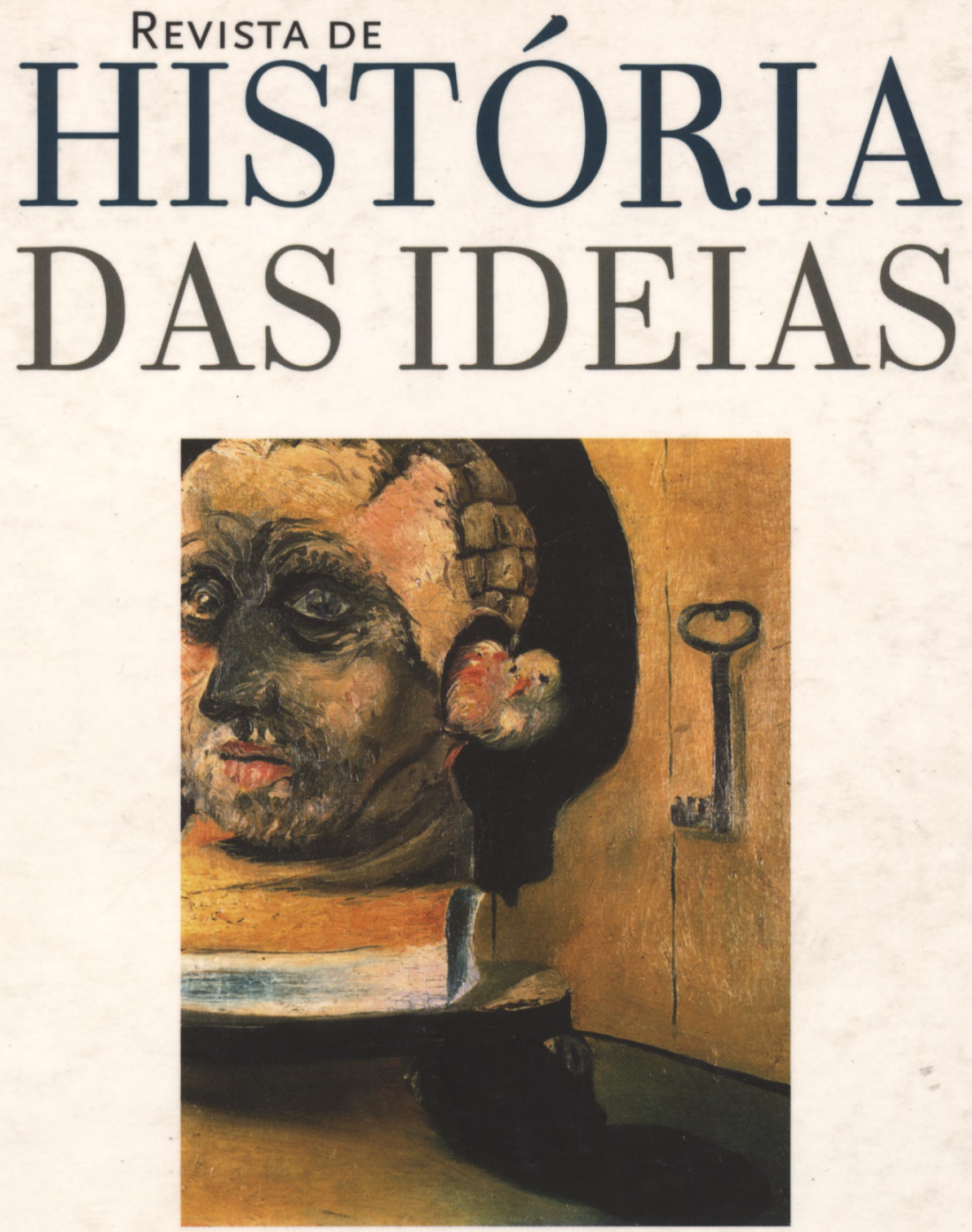

OS INTELECTUAIS E OS PODERES

Volume 24, 2003

INSTITUTO DE HISTÓRIA E TEORIA DAS IDEIAS

Faculdade de Letras da Universidade de Coimbra 


\title{
CRISE E ENCICLOPEDISMO \\ A tarefa dos intelectuais segundo Bento Caraça
}

\begin{abstract}
A intervenção do intelectual trouxe à cena da história, como elemento constituinte, um pacto com a verdade. Em todos os textos - ensaios complexos para elites ou artigos em jornais e revistas lançados ao entendimento de todos, petições ou abaixo-assinados, até manifestações de rua transfiguradas em texto precário investido de uma carga simbólica ou absoluta - a palavra do intelectual desenhou uma figura da verdade que intervinha na espessura da história para esclarecer e mobilizar.

As figura da verdade são as personagens da história dos intelectuais. É nelas, e não nas relações mais ou menos mediadas entre as disposições subjectivas e o devir histórico, que reside o elemento decisivo da inteligibilidade da condição intelectual.

Entre Julien Benda e Pierre Bourdieu não encontramos uma noção de intelectual, imprecisa, à procura da coerência de uma determinação objectiva. Nas suas páginas e nas de Romain Rolland e Henri Barbusse, Henri Lefèbvre e Paul Nizan, Jean-Paul Sartre e Raymond Aron, sem esquecer Michel Foucault é a definição de figuras da verdade e a definição de uma história (para não dizer uma galeria) que se torna legível, e só assim é legível, como os múltiplos modos de verdade por que se nos tornou acessível.
\end{abstract}

\footnotetext{
* Faculdade de Letras da Universidade de Coimbra e CEIS20.
} 
Todos eles - precisamente porque, provavelmente, a própria figura de intelectual - entram em cena munidos da pré-compreensão de que a história é legível, seja na globalidade de uma filosofia da história seja na modéstia de objectos parciais correlativos da finitude da nossa condição. A oposição entre os que denunciam a ilusão dos intelectuais - seja ela a ilusão de que é preciso escrever a história -, equivocados por coincidirem com a transcendência de uma filosofia da história que se realiza, e os que defendem o pragmático realismo da referência ao real como simples leitura do que ocorre no modo do presente só pode ter lugar no espaço de um pensamento da visibilidade da história.

O elemento correlativo do estatuto de intelectual é a conversão da história em cena integralmente visível, ora no presente ora no futuro, quer se dê a ver na instante densidade de acontecimentos paradigmáticos quer no espaçamento do fluir diacrónico.

Uma primeira condição de possibilidade histórica e teórica da instituição do intelectual como figura do pensamento é a convição de que a história não mantém reservas de sentido. $\mathrm{O}$ intelectual, mais do que solidário, é uma consequência genuína do progresso considerável do pensamento moderno, se aceitarmos que ele consistiu, como pretendeu Sartre, em reduzir "o existente à série das aparições que o manifestam" (L'être et le néant, p. 11). Admita ou não que a posse da lógica imanente da história é a maior força da verdade de que é portador, a emergência do intelectual requer, como correlato que se torna constituinte do seu próprio estatuto, uma concepção de história de que os homens são sujeitos e artífices.

Neste ponto, talvez, manifesta-se a singularidade do intelectual. O intelectual não é, simplesmente, aquele que pensa nem sequer aquele que pensa com um determinado grau de consciência intencional ou de coerência; não é, também, aquele que pensa abstracções sofisticadas; nem é em rigor identificável com o cientista, o filósofo ou o artista.

O elemento diferenciador que demarca todas as práticas de pensamento da figura intelectual é a mediação pelo sentido da história. O artista, o filósofo ou o cientista podem desenvolver os seus trabalhos atendendo unicamente aos acontecimentos regionais do seu próprio campo de actividade e mesmo que essas obras produzam efeitos sociais e políticos intensos. Mas a obra do intelectual é de outra ordem que o produto de uma imaginação criadora. A obra do intelectual consiste em extrair, da complexidade e da mistura que é o movimento da história, aquilo que 
identifica o seu sentido; por mais específico que seja o ponto de partida, por mais especializado que pareça ser o ângulo de abordagem, pertence à singularidade do intelectual tornar a especificidade do fenómeno 0 elemento significante do curso da história.

É por esta decisiva relação com a história que o intelectual se afirma como uma figura moderna, apesar das pertinentes observações do Jacques Le Goff de Os intelectuais na Idade Média. O facto de os elementos que definem o sentido da história caberem completamente na racionalidade de um discurso é o pre-suposto decisivo da enunciação intelectual.

Assim, uma reflexão sobre as condições filosóficas da figura do intelectual organiza-se em torno de dois pólos fundamentais: por um lado, o trabalho da consciência, entendida como instância última da afirmação individual, ao mesmo tempo gnoseológica e moral; por outro lado, a noção de história, concebida como fluir ordenado e inteligível. As figuras da verdade desenham, em formas muito variáveis, as relações possíveis entre consciência e história e são estas relações que definem o espaço intelectual. A noção de intelectual, por conseguinte, está congenitamente ligada ao processo de mediação recíproca da consciência pela história e da história pela consciência - que Karl Jaspers designou por "consciência epocal". Por isso, quando a mediação da consciência é uma história em crise a mediação da história pode ser uma consciência dilacerada também por um abismo nadificador. Mas o que pôde ter acontecido, e aconteceu, nas artes, na filosofia, talvez mesmo nas ciências não poderia ocorrer no campo intelectual: a consciência ou, em outras terminologias, a razão sustentam-se a si próprias mesmo se - ou porque - estão desligadas da determinação da história. A indeterminação que afecta a realidade histórica não atinge a consciência intelectual (ponto decisivo na demarcação entre o intelectual e o artístico): mas, se não quiser tomar-se a si própria como objecto de análise privilegiado, o trabalho da consciência, como "consciência epocal", consiste em desenvolver uma analítica do presente capaz de decifrar o que está a acontecer.

É insuficiente dizer, pois, que, na figura do intelectual, o correlato da consciência é, simplesmente, a história. Não é em estado de objecto-a-conhecer que a história se propõe ao intelectual; ou melhor, não é numa história que se apresenta como objecto a conhecer que o intelectual reconhece o seu próprio campo: precisamente, ele não é historiador. É sempre perante uma situação dilacerada, opacificada, incerta que o intelectual desenvolve o seu discurso. De certo modo, pode dizer-se que 
só essas situações constituem o campo de emergência da intervenção intelectual: a condição de possibilidade da intervenção intelectual é que a história, impondo-se como correlato da consciência, seja uma história-em-crise.

Esta linha esquemática de uma epistemologia do conceito de intelectual, que pretendemos desenvolver em outro trabalho, esclarece-se e concretiza-se, simultaneamente, se a referirmos a Bento de Jesus Caraça, em particular a um aspecto do seu pensamento e da sua intervenção: as relações entre crise (crise histórica, crise civilizacional) e enciclopedismo. É no âmbito da noção de cultura integral, que constitui a nervura da sua atitude enciclopédica, que o presente-em-crise pode tornar-se a situação germinal de um futuro mais solidário.

\section{Um pensamento $d a$ crise}

A viva consciência do presente como crise, prolongada na conviç̧ão de que se trata de uma crise global, implica um esquema interpretativo que só pode ser igualmente globalizante.

Bento Caraça pensa o seu presente em nome do seu futuro. Como o seu futuro é o nosso passado, nem sempre nos damos conta de que o estabelecimento das coordenadas que mostram o presente como um feixe de futuros possíveis constitui um imenso trabalho da intuição e da razão, uma viagem radical não só aos acontecimentos mas aos fundamentos dos acontecimentos. Pensar o presente é pensar uma provisória estabilização de passados tornada, ao mesmo tempo, situação de emergência de futuros possíveis. Mas pensar o presente sob a óptica militante de quem quer um futuro implica reduzir progressivamente os futuros possíveis em nome dos futuros desejáveis.

Uma reinterpretação actual da obra de Bento de Jesus Caraça não deixará de registar um peculiar materialismo histórico subjacente que não se confunde com qualquer daquelas sociologias denunciadas com tanta veemência por Antonio Gramsci ${ }^{(1)}$.

(1) Cf. António Gramsci, "Notas críticas sobre uma tentativa de Manual Popular de Sociologia", in Obras escolhidas, vol. I, Lisboa, Editorial Estampa, 1974, pp. 169-246. 
Bento Caraça não tem a história no bolso ${ }^{(2)}$. Em várias oportunidades, explicitou mesmo fundadas reservas à confusão entre "pensamento do futuro" e "finalismo": uma sólida rejeição do determinismo sustenta a sua atitude existencial e a sua posição teórica.

Logo em 1933 na conferência que estabelece os nítidos contornos do seu pensamento e da sua intervenção - refiro-me, claro, à conferência A cultura integral do individuo - problema central do nosso tempo -, Bento Caraça lembra: "O que o mundo for amanhã, é o esforço de todos nós que o determinará"(3). Anos volvidos, em recensão de 1940 à obra de Vasco de Magalhães Vilhena sobre O progresso - história breve de uma ideia, Bento Caraça não perde a oportunidade de colocar restrições ao "jeito finalista" que resulta da confusão entre o pensamento histórico das hipóteses de futuro e decifração do "segredo do destino" (C., 269).

O elemento nuclear do "pensamento do presente" desenvolvido por Bento Caraça é a noção de transição, que não ocorre desligado, evidentemente, da noção de crise: "O que estamos actualmente vivendo e sofrendo não é apenas uma borbulhagem fugaz, destinada a passar como tantas coisas passam, sem deixar sinal; é, muito pelo contrário, uma época de transição, uma ponte de passagem entre aquilo que desaparece e o que vai surgir" (C.E., 100). Ou, em texto de 1935: "Espera-se qualquer coisa que ainda não chegou" (C., 145). Formulação próxima, para não dizer solidária, da formulação de crise proposta por António Gramsci: "A crise consiste, justamente, no facto de o velho estar a morrer e o novo não poder nascer" (4).

Crise e transição constituem, pois, noções recorrentes ao longo de toda a obra de Caraça, embora uma fenomenologia da crise seja necessária para identificar, na crise do momento, os sinais de uma crise histórico-civilizacional. Quando Bento Caraça escreve: "Vivem-se hoje horas

(2) Cf. A. Gramsci, ob. cit., p. 180.

(3) B. J. Caraça, "A cultura integral do indivíduo - problema central do nosso tempo", in Cultura e emancipação (1929-1933), Obra integral de Bento de Jesus Caraça, Edição crítica (org. Luís Augusto Costa Dias, Helena Nunes e António Pedro Pita), Campo das Letras, Porto, 2002, p. 99. Nas próximas citações, no texto, usa-se a sigla C.E. e indicação de página.

Os textos não incluídos nesta edição serão citados de Conferências e outros escritos, Lisboa, 1970. Sigla: C. e a indicação de página.

(4) Cf. Dominique Grisoni e Robert Maggiori, Ler Gramsci, Lisboa, Iniciativas Editoriais, 1974, p. 231. 
trágicas de ansiedade", e sublinha o sentimento imediato de uma tragédia imensa, é para continuar nestes termos: "sobre as nossas cabeças paira a ameaça sombria da repetição, ampliada, da catástrofe de há 20 anos; o momento é de crise, e essa crise é tanto mais violenta quanto maior a desproporção entre a decrepitude das formas e a viveza de ritmo na vida que essas formas devem conter" (C., 131).

As crises, repetindo-se, são afinal ondas várias da mesma crise, e é esta que importa compreender e resolver porque este pensamento da crise não é um pensamento em crise. Pela peculiaridade do seu racionalismo, que tem a forma de um iluminismo que se pôs à prova das contradições sociais do devir histórico, Bento Caraça emancipa as coordenadas do seu próprio pensamento dos processos de erosão que puseram em crise outras concepções.

De certo modo, está na ponte - mas não corre perigo de cepticismo: sente-se desligado do mundo que desapareceu embora o mundo novo ainda não exista senão limitado ao pensamento que o anuncia e a uma limitada experiência que o prefigura, e que ocorre num dos seus primeiros textos, de 1933, nesta fórmula engenhosa: "a estrutura política das cinco sextas partes do mundo é a mesma que era há quinze anos" (C.E., 86), repetida dois anos depois na conferência sobre a "Escola Única" (C., 107).

Pensamento da crise e não pensamento em crise porque um elemento constituinte da mundividência de Caraça é a convicção de que, embora num contexto civilizacional de crise, nem tudo está em crise. Trata-se, aliás, de uma convicção constituinte do próprio conceito de "intelectual": pertence à sua estrutura pre-conceitual a conviç̧ão de que o pensamento (ou "a razão" ou "a consciência" ou "o espírito") mergulham num fundo luminoso e distinto da noite do mundo.

Bento Caraça escreve, a propósito, no segundo número de Globo: "Na realidade, [sublinhemos este "Na realidade"] nem a razão, instrumento supremo nem a vontade de justiça estão em crise. O que está em crise na Europa e no mundo, é a estimação dos meios de impor a razão e de realizar a justiça, super-estruturas dum mundo social cujas bases se decompõem rapidamente. O que a Europa e o mundo reclamam dos intelectuais - é a coragem de assumir a responsabilidade de soluções capazes de integrar mais profundamente a Razão e a Justiça na existência comum dos homens" (C.E., 96).

Assume, por isso, uma importância central a definição estratégica dos modos de actuação das ideias portadoras de Razão e de Justiça sobre 
o curso geral da História. Ora, reconhecer que não é por um princípio imanente à História que vão realizar-se as determinações da Razão e da Justiça é admitir, operativas na cena do devir, uma consciência e uma vontade.

O esquema de filosofia da História orientador do pensamento de Caraça é dual. Mas a dualidade não se limita, explicitamente, à forma de uma dualidade das classes. Em orientação consonante com os princípios fundamentais do materialismo histórico, admite, sem dúvida, a dimensão social dessa dualidade sob a forma de "luta de classes" mas integra esta dualidade numa outra dualidade que a transcende, metafisicamente definida por um princípio de unidade ou harmonização, que constitui o traço mais vivo da sua filosofia da história.

Tal como se nos oferecem no pensamento de Bento Caraça, os elementos dessa dualidade não são os elementos definidores de uma relação de produção, - nem directamente nem indirectamente. É que, embora sensível, ao que nos anos trinta era possível identificar no movimento da Revolução russa, Bento Caraça permanece, desde os primeiros textos, não só um leitor mas um pensamento que se organiza nas coordenadas de Romain Rolland.

Terá sido no pensamento de Romain Rolland que Bento Caraça encontrou um elemento invariante do seu ideário, desdobrável em duas noções: a noção de que dois elementos contrários são a condição de uma harmonia maior e a noção de que a unidade humana não é um facto mas um princípio, uma finalidade virtual permanentemente posta à consideração da consciência e da vontade dos homens.

Todos conhecem as célebres páginas em que Bento Caraça desenvolve, "ao menos nas suas linhas gerais, [a] lei à qual se subordine todo o desenvolvimento" (C.E., 101) histórico. Escreve: "Creio que essa lei existe e pode formular-se, pouco mais ou menos, nos seguintes termos: no seio das sociedades humanas manifestam-se permanentemente dois princípios contrários - o individual e o colectivo - de cuja luta resultará um estado superior dessas mesmas sociedades, em que o primeiro princípio - o individual - chegado a um elevado grau de desenvolvimento, se absorverá no segundo" (C.E., 101-2).

Esses princípios estão permanentemente operativos, "mesmo nos períodos de tranquilidade, as forças íntimas que trabalham a estrutura social não estão em repouso" (C.E., 104). Mas se o dinamismo imanente à história resulta do conflito entre os princípios contrários em presença, 
é trabalho dos intelectuais, cuja especificidade é necessário reconhecer, construir (porque não é um dado) o princípio superior que haverá de harmonizar os contrários.

Do ponto de vista da determinação teórica do conceito de "intelectual", esta formulação é da maior importância. $O$ intelectual torna-se um delegado da harmonização da história, incumbido de diagnosticar a crise na exacta medida em que pode tratar da sua resolução. Por isso mesmo que diagnostica o presente como conflito (ou crise), o discurso intelectual, como discurso da resolução da crise, toma forma no interior de uma filosofia da história.

Como pode ler-se em várias páginas de $A$ cultura integral do indivíduo - problema central do nosso tempo, o pensamento de Bento Caraça é um pensamento da unidade, ou melhor: um pensamento da unificação: "Cada fase da luta é um passo novo dado no caminho para a unidade do individual e do colectivo" (C.E., 107), definição de "um estado superior da unidade" (C.E., 114).

No mesmo ano de 1933, e em artigo publicado também no mês de Maio, a noção reaparece: "A humanidade segue, no seu caminho, uma evolução no sentido certo - a unificação, numa síntese que tem qualquer coisa de grandioso e belo, da potência individual e colectiva, [...] que [...] permitirá o desaparecimento do antagonismo entre o indivíduo e a colectividade" (C.E., 82). E, em 1940, exalta a "síntese grandiosa do indivíduo e da colectividade" referida na conferência de 1933, actualizada pela descida aos infernos dos sete anos que constituem o trágico intervalo entre os dois textos (cf. C., 277).

Por conseguinte, não só não existe qualquer contradição entre um pensamento da crise e um pensamento da unificação como, pelo contrário, no horizonte da racionalidade subjacente ao discurso intelectual, a unificação constitui o desenlace lógico, moral e ontológico da crise bem como o seu correlato metafísico.

Em tese geral, a crise é o resultado de uma afirmação singular (individual ou grupal) que resiste a socializar-se, isto é, a transformar-se numa colectividade mais rica. Numa acepção teórica estrita, a identidade contemporânea da crise é a crise do capitalismo. Escreve Bento Caraça: "A burguesia, após a sua ascensão ao poder, não resistiu ao anquilosamento que vimos [...] ser característica essencial das classes dirigentes. Depressa cessou a harmonia dos seus interesses com os interesses gerais. Os seus fundamentos económicos - livre concorrência e propriedade 
privada - cedo se tornaram, pela acção implacável da evolução acelerada do século XIX, em armas terríveis que ela brandiu em seu exclusivo proveito". Depois, o muito célebre diagnóstico: "A civilização de base capitalista tornou inoperantes os princípios de liberdade individual e de igualdade, para não falar já no da fraternidade que só por sarcasmo se pode pretender que esteja incluído hoje entre as ideias dominantes da governação" (C.E., 110).

A crise é, então, o desajuste entre um sentido do todo (C., 187) inscrito nos princípios doutrinários da Revolução Francesa e o sentido parcial decorrente da apropriação privada dos meios de produção e da riqueza produzida. Ainda não há crise quando os princípios que definem o sentido do todo movem o conjunto da sociedade, a crise instala-se quando as exigências do sentido parcial limitam a expansão daqueles princípios.

A crise sobrevem quando uma concepção perde a sua vitalidade englobante e quando o sentido do todo se converte, para lembrar uma famosa definição, em relação imaginária dos sujeitos com as suas condições reais de existência - uma falsa consciência ou uma "consciência mistificada", título da famosa obra de Norbert Guterman e Henri Lefèbvre, publicada em 1936-, que se torna obstáculo à expansão das novas afirmações individuais.

\section{Uma filosofia da história e da cultura}

O trabalho de um pensamento da crise que não seja um pensamento em crise consiste em reunir os elementos ainda dispersos e constituir um (novo) sentido do todo. É, por isso, um pensamento da unificação.

Pensar a crise é o trabalho específico do intelectual. Ou, como escreveu Romain Rolland: "o trabalho do pensador (e também do sábio) está, precisamente, em apreender os contrários e explicá-los por um princípio superior, ou (se se trata de um artista) em harmonizá-los nele"(5).

Neste sentido, e por muito difusa que se encontre nas suas páginas ou disfarçada em considerações alheias, há no pensamento de Bento Caraça uma tematização própria do trabalho intelectual.

(5) Romain Rolland, in Jean-Bertrand Barrère, Romain Rolland por ele próprio, Lisboa, Portugália Editora, s.d., p. 60. 
O intelectual desenvolve um trabalho de reajustamento. Sendo a crise, como vimos, o desajuste entre o sentido do todo implícita numa ideia e a efectiva capacidade desse sentido do todo para responder a necessidades sociais renovadas, o trabalho do intelectual consiste em reajustar o sentido do novo e as necessidades sociais.

Este trabalho envolve uma selecção e uma síntese. A selecção resulta da circunstância de nenhuma concepção do mundo constituir uma totalidade homogénea. Uma teoria, os sistemas filosóficos ou científicos, estabelecem-se segundo um princípio de desenvolvimento desigual porque se organizam a partir de bases com longevidade histórica diferente. Portanto, pensar a crise é avaliar as diferenças de validade histórica do complexo de elementos em actividade. Admite-se mesmo a possibilidade de, numa concepção tornada globalmente inoperante, haver elementos constituintes que podem continuar eficazes: "da etapa anterior, alguma coisa, às vezes muito, ficou definitivamente adquirido" (C.E., 106). Certamente, como veremos adiante, em todas as áreas de actividade humana, haverá aspectos específicos e outros que dão configuração global a uma época ou a uma mundividência. Ora, é pela sua relação com a construção de mundividências que o intelectual se distingue do cientista, do filósofo ou do artista: em profunda relação epistemológica com as categorias de "história" e de "humanidade", o intelectual é o que pensa a crise do ponto de vista da sua superação: de certo modo, só está habilitado a pensar a crise porque a condição de possibilidade do seu discurso reside no primado ontológico da continuidade sobre a fragmentação e da harmonia sobre o conflito.

Compreende-se, nesta óptica, que o modo de trabalho do intelectual seja o modo do músico e não o modo do pintor. Uma vez mais reencontramos Romain Rolland: "Para lhe falar verdade sobre a minha maneira de trabalhar [escreveu a um correspondente, em 1909], o meu estado de espírito é sempre o de um músico, nunca o de um pintor"(6).

A história, como a música, organiza-se no tempo e o desenvolvimento da música, como o desenvolvimento da história, é a progressiva construção de uma harmonia que vai resolvendo sucessivamente as antinomias de cada fase. Que Bento Caraça tenha sido desde sempre um apaixonado melómano é uma consideração biográfica da qual não ousamos extrair conclusões.

(6) Romain Rolland, in idem, ibidem, p. 29. 
Mas não será irrelevante anotar, de passagem, que, ao referir a ligação das artes às condições sociais em que foram produzidas, Bento Caraça reserva um lugar à parte à música: a ligação da literatura, arquitectura, cinema ou dança é mais forte do que a ligação da escultura e da pintura, e a força desta ligação superior à da música. Não tratamos, agora, de analisar esta hierarquia das artes. Mas unicamente de sublinhar ser a música, para Bento Caraça, de todas as artes, aquela cujas condições de produção se reveste de mediações mais longínquas e mais subtis. Se uma teoria se constrói à maneira da música e não da pintura, quer dizer, estabelecendo-se no tempo e não no espaço, mais exigente, e ao mesmo tempo mais necessário, se torna o trabalho de selecção do intelectual. Seleccionar é avaliar a possibilidade de os vários elementos constituintes de uma concepção serem reintegrados numa concepção inovadora.

Por isso mesmo, o trabalho de selecção é correlativo do trabalho de síntese. Uma questão coloca-nos no problema: "as elites propulsionadoras, em cada período histórico, do desenvolvimento científico, literário, artístico, foram realmente aquelas que, nesse período, ditaram a forma de constituição da sociedade, a orientaram, regularam o seu funcionamento orgânico? por outras palavras, elite científica e cultural e classe dirigente são a mesma coisa? ou, melhor ainda, a primeira está compreendida na segunda?" (C.E., 115).

A interrogação sugere a resposta. Mas, acima de tudo, anuncia o pensamento em que assenta a resposta. A direç̧ão política da sociedade não é uma mera questão política (ocupação de lugares, troca de influências, estratégias de sobrevivência), é, antes de mais, a construção desse sentido do todo e, neste sentido, uma questão profundamente cultural.

O pensamento de Bento Caraça demarca-se, todavia, da doutrina seareira da primazia da revolução das mentalidades sobre a revolução política. Ao contrário do individualismo inerente à concepção seareira, pelo menos na configuração exemplar que lhe deu António Sérgio, Bento Caraça mostra-se convicto de que sobre "a lei primária de interdependência das coisas e dos seres do Universo, de modo tal que coisas e seres nos aparecem definidos sempre pelas suas relações no meio ou grupo em que estão integrados" (C., 185) está fundado o primado do grupo no qual "tem a sua raiz aquela orientação segundo a qual só a mudança das condições exteriores ao homem, condições de meio e instituições sociais, pode levar ao aperfeiçoamento e progresso desejados" (C., 184). 
Este gesto de adesão teórica ao primado do grupo não significa que Bento Caraça desvalorize a importância do intelectual ou, como lhe chama mais frequentemente, as elites. Pelo contrário. Uma releitura global das suas biografias, que está ainda por fazer, irá mostrar como o trabalho (do) intelectual se conjuga necessariamente com o trabalho do homem de ciência ou do artista: o homem de ciência ou o artista constituem focos de rupturas, enunciações de uma evidência suspensa, interrupção de um passado reconhecido e aceite; o intelectual traz o momento de síntese das ideias dispersas mas unificáveis.

Admitamos que seja lícito integrar o ensaio consagrado a Galileu numa reflexão sobre o intelectual. Bento Caraça mostra de que modo é que Galileo libertou o seu (e o nosso) olhar de constrangimentos anteriores, descontextualizou os factos observados das respostas dadas e, de certo modo, preparou a recontextualização dos factos num outro sentido de totalidade. Haverá um momento intermédio entre a dissolução de respostas antigas e a génese de novas respostas, uma suspensão, uma pausa?

O ensaio sobre Galileo talvez dê resposta a esta pergunta. Só um princípio de outra resposta permite começar a descolar da anterior porque só a partir de uma hipótese já em formação as respostas aceites se mostram infundadas.

O trabalho do intelectual é, pois, não só necessário mas insubstituível. É pelo ângulo de cada especialidade que uma síntese global revela as suas primeiras fragilidades. Mas é necessário estar, ao mesmo tempo, profundamente de acordo com o seu tempo e profundamente em avanço sobre o seu tempo para perceber quais são as fragilidades regionais que implicam fragilidades globais.

Como, provavelmente, Galileo se deu conta do alcance teológico-político-científico dos seus trabalhos no domínio da astronomia, Bento Caraça considera a conferência sobre Galileo, antes de mais, uma história do heliocentrismo (C., 67).

Os adversários, pelo menos, perceberam que por essa brecha especializada entrava na sua mundividência um princípio de dissolução de mais vastas consequências.

O trabalho de Galileo, como o trabalho de qualquer intelectual no campo problemático de Bento Caraça, reveste-se, por isso, sempre, de uma importância científica e de uma importância moral.

Tem uma importância científica porque é por seu intermédio que se dá a extensão progressiva do património, isto é, o "alargamento constante, 
evidente aos olhos de quem queira ver, de todo o conjunto de possibilidades e aquisições humanas" (C., 138).

Porém, o trabalho do intelectual não é auto-suficiente. Não é uma simples invenção individual: tem condições que são sociais, condições constituídas pelo património de conhecimentos existente, do qual sempre se parte e do qual se está dependente mesmo que seja para depois o negar. E, por outro lado, cada nova aquisição (invenção, descoberta, lei) haverá de dar forma a um novo sentido de todo que integrará progressivamente mais indivíduos (cf. C., 138).

Dois elementos: a extensão progressiva do património e integração progressiva dele. A primeira, revela a fecundidade do trabalho de cada intelectual. A segunda, a importância moral de que se reveste o seu contributo. Mas, como Bento Caraça sublinha, a relação entre ambos faz-se sob a forma da acção recíproca e não da simples causa-e-efeito.

Detectar a importância moral imanente aos desenvolvimentos científicos de Galileo é já colocar o problema da nova síntese necessária à resolução da crise. Determinar a importância moral de (novos) enunciados científicos equivale a reconstruir, a partir destes (novos) propostas, um novo "sentido do todo".

Já o dissemos: na obra de Bento Caraça desenvolve-se um pensamento da unificação porque é seu pressuposto "a lei primária de interdependência das coisas e dos seres do Universo, de modo tal que, coisas e seres nos aparecem definidos sempre pelas suas relações no meio ou grupo em que estão integrados". Portanto, sobre o pano de fundo deste princípio de interdependência ontológica, um pensamento da crise que seja, como é o caso, um pensamento da superação da crise só pode ser um pensamento que procura os elementos de uma nova unificação porque nem a realidade da interdependência nem o princípio organizador da unificação estão em causa.

Organizar uma nova síntese que permita aos homens situarem-se no mundo é a tarefa que Bento Caraça sente ser a do seu tempo.

A cultura é afinal um princípio de orientação, é o conjunto de aquisições que permite a cada ser humano encontrar o seu lugar. Como esse lugar não está antecipadamente definido porque o universo moderno se laicizou - o laicismo é um aspecto nuclear do pensamento de Bento Caraça -, compete a cada um encontrá-lo, constituí-lo, descobrindo afinal que determinar o seu lugar é, afinal, formar-se como homem. 
É neste contexto que Bento Caraça enuncia a noção de homem culto. É um enunciado famosíssimo, que cintilou durante décadas em várias gerações.

Recordo esse passo: "O que é o homem culto? É aquele que: $1^{\circ}$ - Tem consciência da sua posição no cosmos e, em particular, na sociedade a que pertence; $2^{\circ}$ - Tem consciência da sua personalidade e da dignidade que é inerente à existência como ser humano; $3^{\circ}$ - Faz do aperfeiçoamento do seu ser interior a preocupação máxima e fim último da vida" (C.E., 117).

A múltipla tomada de consciência em que consiste este processo é, afinal, um desdobramento de unificações. Cada um coloca para si próprio a tarefa de formar-se perante si próprio, perante os outros e perante $o$ cosmos, - se quisermos num tripla dimensão moral, social e cósmica. É um trabalho que cada um exerce sobre si próprio e em que rejeita os elementos contingentes porque o horizonte é, sempre, o da interdependência de todos os seres e de todas as coisas do universo.

Neste sentido, a tarefa cultural é necessariamente sistemática. Contudo, é possível distinguir numa área de conhecimento aquilo que constitui a sua especificidade e aquilo que pode dar forma à configuração particular de uma época. Num conhecido texto Bento Caraça escreve: "Em cada ramo do conhecimento há o que é do domínio do especialista e o que é do domínio geral, aquilo que só uma vida inteira de trabalho consegue apreender (quando o consegue) e aquilo pelo qual êsse ramo entronca na corrente geral das ideias e da civilização".

Repare-se: por um lado, tudo o que, no trabalho especializado, é e permanecerá individualizado; por outro lado, anote-se a metáfora, o que entronca, isto é, o que se des-individualiza para permanecer activo, o que ascende ao curso comum, o que se realiza na interdependência de todos os seres e de todas as coisas.

\section{A dimensão enciclopédica da cultura integral}

Acabo de citar um passo extraído da apresentação da Biblioteca Cosmos, estampada nas páginas iniciais do primeiro volume, publicado em 1941. É a expressão mais justa para sintetizar o sentido da Biblioteca.

A Cosmos não é apenas uma Biblioteca, uma colecção de livros mais ou menos ordenados: é o concentrado da filosofia da cultura de Bento Caraça e verdadeiramente uma enciclopédia do homem culto moderno. 
Como se conclui da já citada (e célebre) definição, a cultura do homem culto não é "o enciclopedismo barato e estéril" (C., 281). E também não se adquire, autodidacticamente, ao sabor de leituras que podem ser dispersas. Este ponto é particularmente impressivo logo num artigo de 1929, em que Bento Caraça apresenta as actividades próximas da Universidade Popular Portuguesa. Em dado passo, refere a "grande maioria, constituída por pessoas que não puderam levar longe os seus estudos" e que "só encontra possibilidade de satisfazer o seu desejo de aprender ou em leituras, por vezes (quase sempre) feitas ao acaso, sem uma orientação definida e lançando portanto a confusão aonde deveriam levar a ordem e a metodização de conhecimentos"(7).

A generalidade da história da Biblioteca Cosmos é conhecida. Mas investigou-se menos, até agora, o princípio organizador da sua coerência interna.

De facto, é já conhecido que, como acontecimento editorial, a Biblioteca Cosmos muito deve ao jornalista e depois editor Manuel Rodrigues de Oliveira, um lisboeta nascido na Rua da Condessa ao Carmo, em 23 de Março de 1911, filho de um marceneiro, falecido em 1932, cujas conviç̧ões republicanas com aspirações culturais o levaram ao curso nocturno da Escola Machado de Castro.

Manuel Rodrigues de Oliveira ingressou em O Século em 1928 e, no ano seguinte, filia-se na Federação das Juventudes Comunistas; é o início de uma intervenção particularmente intensa, que o conduz a funções de responsabilidade política. Em Abril de 1934, no rescaldo do movimento de 18 de Janeiro, é preso e conduzido ao Governo Civil, de onde é levado para o Aljube e depois para o Forte de Peniche. É julgado e condenado e deportado para Angra do Heroísmo (8 Junho 35). Aí se encontra ou (reencontra?) com Bento Gonçalves, preso em Novembro 35, no regresso de Moscovo. Vários testemunhos sobre esse período, nem sempre coincidentes referem o papel determinante que Bento Gonçalves teria tido na eclosão da ideia de fazer uma editora.

Libertado em Fevereiro de 1936, Manuel Rodrigues de Oliveira volta ao continente e regressa ao jornalismo como correspondente da revista A noite brasileira: "ganhei muito dinheiro, pagavam-me em dólares". É então que aceita parceria com um ou dois conhecidos dos tempos de

(7) Cf. A. Vilaça, Bento de Jesus Caraça - militante integral do ser humano, Porto, Campo das Letras, 2000, p. 267. 
O Século, proprietários da falida Sociedade Tipográfica Editorial e da Editorial Cosmos. A escritura, de 27 de Outubro de 1939, precede uma significativa viragem de orientação editorial, simbolizada pela própria alteração do nome: de Editorial Cosmos para Edições Cosmos.

É neste contexto que Bento de Jesus Caraça é convidado para organizar a Biblioteca Cosmos.

Como iniciativa editorial, a Biblioteca Cosmos não é muito diferente de outras colecções que se tinham afirmado desde o século XIX. Mas há dois pontos que marcam uma diferença substancial.

O primeiro prende-se com uma maior rigor de objectivos. Bento Caraça não pretende reeditar, com propósitos de divulgação, um simulacro da "Biblioteca do Povo e das Escolas". O objectivo não é divulgar conhecimentos para que cada indivíduo possa saber sempre mais coisas. O objectivo é criar os meios de definição de uma cultura integral que permita, a cada um, situar-se no seu tempo.

O segundo: sistematicidade. Num artigo de 1929, já referido, Bento Caraça lamenta que uma grande maioria de indivíduos não tenha podido satisfazer na escola a necessidade de conhecimento e que só o possam fazer "ou em leituras, por vezes (quase sempre) feitas ao acaso, sem uma orientação definida e lançando portanto a confusão aonde deveriam levar a ordem e a metodização de conhecimentos ou em conferências, que, em geral, pela especialização do assunto, e pelo nível cultural suposto pelo conferente no auditório, ficam fora da sua compreensão".

A estratégia a que subordina as actividades da Universidade Popular era a da organização, do plano, da sistematicidade; quando fala das conferências e palestras, refere que serão feitas "obedecendo a um plano cuidadosamente estudado".

A preocupação, que perpasssa por todos os textos, é transferida para a Biblioteca Cosmos. A perspectiva é análoga. Mas, por muito importantes que sejam os pontos de coincidência, uma linha de demarcação evidencia uma clara consciência quanto à transformação dos meios de intervenção cultural.

Bento de Jesus Caraça percebe que mudaram as condições e as exigências de socialização cultural: ao emancipar-se do contexto da escolarização e tornar-se portátil, a cultura deixa de estar circunscrita a lugares de acesso privilegiados.

Posto é que a coerência doutrinária introduza elementos que regulem as novas condições de circulação. 
Ora, essa coerência existe e é voluntária. A Biblioteca Cosmos desenvolve um pensamento laico e estuda o aparecimento do homem como modalidade da existência da vida e o aparecimento da vida como resultado de circunstâncias naturais; há uma inteligibilidade imanente da natureza que dispensa qualquer transcendência criacionista; note-se não só a exiguidade da secção "Filosofia e religiões" ( 3 obras) mas sobretudo a redução histórico-antropológica do fenómeno religioso, patente na obra consagrada ao cristianismo, da autoria do Padre Alves Correia, em que sobreleva a dimensão da mensagem religiosa, e na circunstância de as religiões serem apresentadas na sua pluralidade: o universo religioso é plural e é redutível à medida humana.

Em segundo lugar, a Biblioteca Cosmos exprime um pensamento evolucionista ou progressivo: a história não é o espaço e o tempo de simples mutações fácticas mas constitui, pelos seus próprios fundamentos naturais, a cena de uma evolução. A filosofia da história, que traz ao devir humano uma inteligibilidade específica, inscreve-se numa filosofia da natureza, na medida em que o histórico possa reduzir-se ao natural, cujo sentido é a redução da estranheza do mundo e a conquista da familiaridade e da segurança.

Assim, encontra-se na Biblioteca Cosmos um pensamento da técnica centrado na tese moderna segundo a qual a capacidade de transformar é a verdadeira medida humana. Neste aspecto, a intervenção de Bento de Jesus Caraça é de longo alcance: trata-se de substituir um universo de referências centrado no artístico-literário por um outro universo de referências cujo núcleo de irradiação seja uma cientificidade culturalmente concebida. É certo que a dimensão técnico-científica é medular da modernidade burguesa e capitalista: mas constitui, para além dessa circunstância epocal, uma resposta profunda da imaginação e do engenho humanos aos problemas e adversidades que o mundo lhes coloca; libertar a capacidade técnico-científica desses limites epocais equivale a reconduzi-la ao limiar de uma nova configuração cultural.

Compreende-se, finalmente, que a Biblioteca Cosmos pretenda transmitir, sobretudo, um pensamento da transição. Um passo da apresentação da Biblioteca é elucidativo: "Quando acabar a tarefa dos homens que descem das nuvens a despejar explosivos, começará outra tarefa - a dos homens que pacientemente, conscientemente, procurarão organizar-se de modo tal que não seja mais possível a obra destruidora daqueles. Então, com o estabelecimento de novas relações e novas estruturas, 
o homem achar-se-á no centro da sociedade numa posição diferente, com outros direitos, outras responsabilidades. É toda uma vida nova a construir, dominada por um humanismo novo".

Em poucos textos Bento de Jesus Caraça formula com tanta clareza a temática da transição, uma transição ao mesmo tempo histórica e civilizacional. Trata-se, como sempre no pensamento de Caraça, de realizar ao mesmo tempo uma dupla tarefa: avaliar a herança histórico-cultural recebida e unir, numa outra mundividência, os elementos cuja validade se mantenha.

Encontramos na Biblioteca Cosmos os sinais de uma larga mediação que faz remontar o leitor a momentos fundamentais de génese do mundo burguês. Bento Caraça faz traduzir obras fundamentais: $O$ Elogio da Loucura de Erasmo, 1511 ( $\mathrm{n}^{\circ}$ 80/81), O Príncipe de Maquiavel, 1516 (n ${ }^{\circ}$ 90/91), Quadro dos Progressos do Espírito Humano de Condorcet, 1795 ( $\mathrm{n}^{\circ}$ 104/105) e A Utopia de Tomás Moro, 1516 (n $\left.{ }^{\circ} 125 / 126\right)$. Quer dizer: três das obras em que é legível o movimento da razão emancipando-se e a de Condorcet, centrada no "progresso", categoria-chave da filosofia da história moderna.

O debate sobre a identidade epistemológica do que, por comodidade, continuamos a chamar Biblioteca Cosmos prosseguirá certamente.

A preocupação subjacente é de natureza enciclopédica, entendendo por enciclopédia, de modo genérico, um corpus em que é legível um equilibrio entre o "saber feito" e o "saber a fazer-se".

Neste sistema, Bento Caraça introduziu uma pluralidade de autoria irredutível a qualquer palavra de síntese. A grande maioria dos volumes são de autoria estritamente individual, e a eles não é anexada qualquer anotação (prefácio, pósfácio, contracapa, badana) subordinada a um eventual propósito de unificação singularizante.

Recordemos: a história, como a música, organiza-se no tempo, e desenvolve-se, como a história, em progressiva construção de harmonia.

O trabalho do intelectual é o modo do músico e não o modo do pintor. Uma Enciclopédia, como a música e a história, é também no tempo que vai expondo o sentido profundo que a anima. Não é um puzzle em que as peças se justapõem até à completude de um desenho. É um texto que se conjuga com outros textos como os sons sucedendo-se produzem uma harmonia mais alta, na condição de guardarmos, no tempo, a memória e a emoção deles. 
O trabalho de pensamento de Bento de Jesus Caraça na edificação da Biblioteca Cosmos foi menos solicitar as peças necessárias à construção de uma forma acabada do que antever o princípio superior governado pela harmonia de todas as diferenças.

Se é justo dizer que ela é o concentrado da filosofia da cultura de Bento Caraça é porque não aspira à redução das vozes múltiplas ao discurso da justeza ou da verdade: a cultura é polifónica. 